\title{
Interleukin-6 in psoriasis: expression and mitogenicity studies
}

\author{
J. T. Elder ${ }^{1}$, C. I. Sartor ${ }^{2}$, D. K. Boman ${ }^{1}$, S. Benrazavi ${ }^{1}$, G. J. Fisher ${ }^{1}$, and M. R. Pittelkow ${ }^{3}$ \\ ${ }^{1}$ Department of Dermatology, ${ }^{2}$ Department of Internal Mediaine, C560A MSRB II, Box 0672, University of Michigan, \\ Ann Arbor, MI 48109-0672, USA \\ ${ }^{3}$ Department of Dermatology, Mayo Clinic, Rochester, Minnesota, USA
}

Received April 27, 1992

Summary. Interleukin-6 (IL-6) is a multifunctional cytokine which has been suggested to function as an autocrine mitogen in psoriatic epidermis. We report here the results of several experiments designed to further examine this hypothesis. Blot hybridization was unable to detect $1.3 \mathrm{~kb}$ IL-6 transcripts in RNA extracted from normal or psoriatic epidermal (keratome) biopsies, suggesting that IL-6 expression is very low in normal and psoriatic epidermis. Therefore, qualitative and semiquantitative PCR/Southern blot analyses were performed on keratomederived RNA, and revealed variable but significantly increased IL-6 mRNA levels in lesional psoriatic relative to normal tissue. To further examine the ability of normal human keratinocytes (NHK) to express IL-6, RNA was extracted from rapidly proliferating secondary NHK cultures. IL-6 transcripts were nearly undetectable by blotting in keratinocytes grown in low-calcium serum-free medium, but low levels could be induced by treatment with $1.8 \mathrm{mM}$ $\mathrm{CaCl}_{2}$. IL-6 transcripts were strongly superinduced after cycloheximide treatment, suggesting that a labile protein regulates IL-6 mRNA levels in these cells. Finally, the mitogenic activity of IL-6 was examined in NHK under varying conditions of cell density and added growth factors. IL-6 did not stimulate high density keratinocyte growth in the presence or absence of other growth factors, but did stimulate clonal growth in epidermal growth factor (EGF)deficient media at high concentrations $(\geqq 10 \mathrm{ng} / \mathrm{ml})$. The proliferative effects of IL-6, but not of basic fibroblast growth factor, were abrogated by monoclonal antibodies directed against the EGF receptor. Taken together, these results suggest that the proliferative effects of IL-6 are mediated indirectly via the EGF/TGF- $\alpha$ receptor, and that autocrine overexpression of IL-6 may be limited in psoriatic keratinocytes.

Key words: Interleukin-6 - Psoriasis - Polymerase chain reaction - Keratinocytes - Cell proliferation

\footnotetext{
* Presented in part at the National Meeting of the American Federation for Clinical Research, Washington, D.C., May 1990
}

Interleukin-6 (IL-6) is a multifunctional cytokine, originally cloned as an interferon (IFN)- $\beta$-like antiviral activity from human fibroblasts [for reviews, see references $20,23]$. In human skin, cutaneous ultraviolet-B irradiation leads to a rapid $(12 \mathrm{~h})$ increase in circulating IL-6 [45], suggesting that the skin may be a prominent source of this cytokine. However, the cutaneous cell type(s) responsible for the production of IL-6 are presently unclear. Fibroblasts, endothelial cells, and vascular smooth muscle cells are generally considered to be prominent sources of IL-6 in tissues [27], whereas large, low density mononuclear cells appear to be the principal IL-6-producing cells in the circulation [1].

Recently, increased levels of biologically active IL-6 have been reported to be present in blister fluid derived from psoriatic lesions [37], although bioactivity could not be detected in aqueous extracts of psoriatic scale [17]. Increased expression of IL-6 has been reported in keratinocytes within psoriatic lesions by immunocytochemical and in situ hybridization techniques [19, 30-34]. However, significantly increased production of IL-6 by peripheral blood mononuclear cells has also been obsrved in psoriatic patients $[19,30]$. Since these cells are capable of entering the epidermal compartment in psoriatic lesions [4], and since proteins as large as albumin are capable of entering the epidermis from the circulation [38], the question arises whether the keratinocyte is the predominant cellular source of IL-6 in psoriasis and other inflammatory skin diseases. Psoriasis is characterized by a marked increase in keratinocyte proliferation [47], and three reports have suggested that IL- 6 is apatient positive growth regulator for human keratinocytes [19, 25, 50]. Taken together, these data have suggested the hypothesis that IL-6 is a major autocrine regulator of keratinocyte growth [19, 26].

Previous data suggesting increased IL-6 gene expression in psoriatic keratinocytes in vivo have been limited to results of in situ hybridization and immunocytochemical experiments [19, 30-34]. Therefore, we investigated alternative methods in an attempt to confirm abnormal expression of IL-6 mRNA and protein in psoriatic epidermis, including RNA blot hybridization, polymerase chain reaction (PCR), and immunoblotting. In addition, 
the effects of seum, calcium, and cycloheximide on IL-6 mRNA levels were investigated in cultured keratinocytes. Finally, in an attempt to clarify the direct effects of IL-6 on keratinocyte growth, we tested the effects of cell density and other growth factors on IL-6-stimulated proliferation in secondary cultures of normal human keratinocytes.

\section{Materials and methods}

\section{Skin biopsies}

After obtaining informed consent with Institutional Review Board approval, keratome biopsies $(0.2-0.4 \mathrm{~mm}$ thick) were obtained from the buttocks of normal volunteers or from lesional buttocks or upper thigh skin of psoriatic volunteers as previously described [46].

\section{Organ culture of keratomed tissue}

Keratome strips were obtained from normal individuals and immediately cut into $1.5 \mathrm{~cm}$ squares. Tissue fragments were either frozen immediately or incubated in keratinocyte basal medium (KBM, Clonetics San Diego CA, USA) at $37^{\circ} \mathrm{C}$ in an atmosphere containing $5 \% \mathrm{CO}_{2}$ for $2-4 \mathrm{~h}$ followed by freezing in liquid nitrogen as previously described [11].

\section{RNA and DNA isolation and blot hybridization}

RNA was extracted from keratome biopsis and organ cultures by guanidinium isothiocyanate lysis and ultracentrifugation exactly as previously described $[11,12]$. Total RNA was extracted from cell cultures using RNAzol (Tel-Test, Friendswood, TX, USA) as directed by the manufacturer. Polydenylated RNA was prepared from total biopsy RNA and from cultured keratinocytes by oligo-dT cellulose chromatography $[11,12]$. RNA quantitation, blot hybridization using random-primed ${ }^{32} \mathrm{P}$-labelled probes, and analysis of specific RNA transcripts by densitometry were performed as previously described $[11,12]$.

\section{Plasmids and hybridization probes}

Plasmid DNAs were prepared by alkaline lysis followed by polyethylene glycol precipitation [3]. Hybridization probes (specific activity $1-4 \times 10^{9} \mathrm{cpm} / \mu \mathrm{g}$ DNA) were prepared by random priming [15] of a $900 \mathrm{bp}$ PstI fragment from the human IL-6 cDNA plasmid $\mathrm{p} \beta_{2} .15$ [28] and a $1.4 \mathrm{~kb}$ Eco RI fragment from the human TGF- $\alpha$ cDNA plasmid psp65C17N3 [9].

\section{Polymerase chain reaction ( $P C R$ )}

For qualitative PCR analysis, total RNA $(1 \mu \mathrm{g})$ was reverse transcribed using 20-30 U avian myelocytomatosis virus reverse transcriptase Seikagaku America, Rockville, MD, USA) and an oligo (dT) primer (Pharmacia, Piseataway, NJ, USA), as previously described [21]. Using Taq polymerase, buffers, and nucleotides provides in a commercial kit (Perkin elmer Cetus, Norwalk. Coun., USA), 30 cycles of amplification $\left(92^{\circ} \mathrm{C}, 30 \mathrm{~s}, 57^{\circ} \mathrm{C}, 30 \mathrm{~s}, 72^{\circ} \mathrm{C}\right.$, $100 \mathrm{~s}$ ) were performed. The upstream IL-6 primer, $5^{\prime}$-TCC TTC TCC ACA AGC GCC TTC GGT CCA-3', was derived from the junction of the first and second exons of the human IL-6 gene [49]. The downstream primer, 5'-TGT TCC TCA CTA CTC TCA AAT CTG TTC T-3', was derived from the third exon. All RNA samples were also tested by PCR for $c$ - $a b l$ sequences using the primers previously described [41]. DNA blots of the PCR products were prepared by alkaline capillary transfer from $1 \%$ agarose gels to derivatized nyon membranes (Zeta-Probe, Bio-Rad, Richmond, Calif., USA) as described by the manufacturer, and hybridized against the IL- 6 cDNA probe under the same conditions used from RNA blot hybridization.

Semiquantitative PCR analysis will be described in detail (G. Fisher, S. Benrazavi, and J. Voorhees, manuscript in preparation). Purified human $\beta$-globin mRNA (Gibco BRL, Santa Clara, Calif., USA) (1.25 pg) was added to $1 \mu \mathrm{g}$ of normal or psoriatic total biopsy RNA, and cDNA was prepared using M-MLV reverse transcriptase (200 U, Gibco BRL) and random hexamers (25 pmol) as primers. Threefold serial dilutions of cDNA were mixed with primers (100 pmol each) for IL-6 (forward, 5'-ACA ACC TGA ACC TTC CAA, AGA TGG-3'; reverse, 5'-CTT AAA GCT GCG CAG AAT GAG ATG-3') and $\beta$-globin (forward, 5-'AAG GCT CAT GGC AAG AAG GTG-3'; reverse 5-'CTG CAC CTG AGG AGT GAA TTC-3'). Amplification was performed using 2 U Taq DNA polymerase (Perkin Elmer Cetus) in $40 \mathrm{mM}$ Tris-HCl pH 8.3, $1.5 \mathrm{mM} \mathrm{MgCl} 2,125 \mathrm{mM}$ dXTP. Amplification was carried out for 23 cycles so that the amount of DNA formed remained proportional to the amount of RNA input. Denaturation was for $30 \mathrm{~s}$ at $92{ }^{\circ} \mathrm{C}$ and annealing was for $30 \mathrm{~s}$ at $57^{\circ} \mathrm{C}$. Extension was for $100 \mathrm{~s}$ at $72^{\circ} \mathrm{C}$ in the first cycle, and prolonged by $3 \mathrm{~s} /$ cycle. After amplification, the $335 \mathrm{bp}$ IL-6 and $201 \mathrm{bp} \beta$-globin products were analyzed by electrophoresis and blot hybridization, using a mixture of ${ }^{32}$ P-labelled IL- 6 and $\beta$-globin PCR products as probes. After hybridization, band intensities were quantitated using a phosphorimager (Molecular Devices). IL-6 band intensities obtained from non-saturating dilutions of input RNA were normalized to $\beta$-globin. Statistical comparison were performed using Student's $t$-test and a two-tailed hypothesis with and without logarithmic transformation of the data.

\section{Cell culture}

Primary cultures of normal human kineratinocytes were prepared as reviously described $[12,36,48]$ from keratome biopsis of adult volunteers less than 30 -years-old or from neonatal foreskins. Subcultures were expanded in either keratinocyte growth medium (KGM, Clonetics, San Diego, CA, USA), or MCDB 153 medium modified for high-density growth as previously described [12]. Subcultures were used in the second to fourth passage. As previously defined [12], 'standard medium' is basal MCDB 153 medium supplemented with ethanolamine, phosphoethanolamine, and hydrocortisone. 'Complete medium' is standard medium supplemented with insulin, epidermal growth factor (EGF), and bovine pituitary extract (BPE). Human dermal fibroblast cultures were prepared from punch biopsies as previously described [12], propagated in modified McCoy's 5A medium (Sigma St. Louis, Mo., USA) containing $10 \%$ fetal calf serum and antibiotics, and used before the tenth passage.

\section{Growth assays}

Glonal growth assays were performed as previously described [31]. Briefly, 500 keratinocytes from primary culture were inoculated into $60-\mathrm{mm}$ dishes containing standard MCDB153 medium and the designated growth factors or additives. Recombinant human bFGF was obtained from Upstate Biotechnology Inc. (UBI, Waltham, MA, USA). Carrier-free rhIL-6 (Biosource International, Camarillo, CA, USA) had a specific activity of $6 \times 10^{6} \mathrm{U} / \mathrm{mg}$, and the $\mathrm{ED}_{50}$ for ${ }^{3} \mathrm{H}$-TdR uptake in B 9 cells was $0.15 \mathrm{ng} / \mathrm{ml}$; rhIL-6 was dissolved in PBS at $1 \mathrm{mg} / \mathrm{ml}$, and diluted into culture medium just to use. Monoclonal antibodies (IgG1 kappa isotype) against EGF receptor (LA-1, UBI) and growth hormone (gift of R. Derynck, Genentech, South San Francisco, CA, USA) were added to culture medium at a final concentration of $2.2 \mu \mathrm{g} / \mathrm{ml} \mathrm{IgG}$ at the time of cell plating. Cultures were incubated without medium change for 10 days, fixed, stained with crystal violet and photographed. The additives used had no effect on plating efficiency, as determined by microscopic examination of the stained plates. Higher density proliferation assays were also performed $[36,48]$ using subcultures of keratinocytes seeded at $1-3 \times 10^{3}$ cells $/ \mathrm{cm}^{2}$ in T25 flasks containing complete MCDB 153 medium. 


\section{Results}

\section{IL-6 expression in vivo}

Figure 1A displays sequential hybridizations of the same RNA blot, containing both total and polyadenylted RNA isolated from five normal and five psoriatic volunteers. In the upper panel, the blot was probed with IL-6 cDNA alone. The blot was then stripped and rehybridized against a mixture of IL- 6 and TGF- $\alpha$ cDNAs of comparable length, specific acitivity, and total activity. The IL-6 probe hybridized to a band of approximately $2 \mathrm{~kb}$ in $40 \mu \mathrm{g}$ of total RNA (left upper panel). This band comigrated with the $18 \mathrm{~S}$ ribosomal RNA band on the ethidium bromide-stained gel prior to blotting (not shown), and was not observed when $5 \mu \mathrm{g}$ of polyadenylated RNA was blotted instead of total RNA ( Right upper panel). When the same blot was rehybridized against the mixture of IL- 6 and TGF- $\alpha$ probes, TGF- $\alpha$ transcripts $(5.0$ and $1.6 \mathrm{~kb})$ were readily detectable and clearly enhanced in lesional psoriatic vs. normal epidermis (Fig. 1A, lower panel). Hybridization of the same blot with TGF- $\alpha$ alone revealed the same 5.0 and $1.6 \mathrm{~kb}$ bands as seen when the mixed probe was used, demonstrating that the $1.6 \mathrm{~kb}$ band is derived from TGF- $\alpha$ and not IL-6 (data not shown). Although no IL-6 mRNA could be detected by RNA blot hybridization in keratome samples of normal or psoriatic skin frozen in liquid nitrogen immediately after harvesting, $1.3 \mathrm{~kb}$ IL-6 transcripts became detectable after $2-4 \mathrm{~h}$ of organ culture of normal biopsies (Fig. 1B).

In order to increase the sensitivity of detection of IL-6 transcripts in normal and psoriatic epidermis, qualitative PCR amplification studies were undertaken. For these analyses, all biopsies were frozen immediately after harvesting, and not subjected to organ culture. The results of one of three qualitative PCR comparisons of IL-6 mRNA levels in normal and psoriatic keratome biopsies are shown in Fig. 2. The results of all three qualitative PCR experiments are summarized in Table 1 . There was no significant difference in the number of positive samples in normal and psoriatic biopsy RNA, as assessed by positive EtBr staining or by blot hybridization of the PCR products. However, a significant increase in the number of strongly-positive bands was evident (Table 1).
Because the qualitative PCR analyses did not allow a reliable comparison of relative IL-6 mRNA levels in normal and psoriatic biopsies, semiquantitative PCR analysis was performed. To verify the linearity of amplification and to provbide an internal standard for comparisons, equal amounts of purified $\beta$-globin RNA were added to each sample prior to reverse transcription. After reverse transcription, $\beta$-globin- and IL-6-specific primers were added in parallel to serial dilutions of cDNA prior to amplification. As shown in Table 2, this analysis revealed that, whereas IL-6 mRNA levels were uniformly low in keratome biopsies of normal skin, IL-6 expression was clearly increased but highly variable in psoriatic lesions (Table 2). These results confirmed the impression derived from qualitative PCR analysis (Table 1) that a strongly positive signal was derived from a much higher proportion of psoriatic samples $(14 / 15)$ compared with normal samples $(2 / 21)$.

\section{IL-6 expression in vitro}

Small amounts of papillary dermis and variable numbers of infiltrating immune/inflammatory cells are unavoidably present in psoriatic tissue specimens. Therefore, IL-6 mRNA levels were analyzed in keratinocyte cultures, which are relatively free of inflammatory and other cell types. Since the presence of hydrocortisone (HC) has been shown to inhibit IL-6 expression in keratinocytes [25], $\mathrm{HC}$ was excluded from the medium for one passage (usually 5-7 days) prior to assay (KGM-HC). Under these conditions, IL-6 transcripts could be detected as a very faint band in $5 \mu \mathrm{g}$ of polyadenylated RNA (Fig. 3A). Switching cultures from KGM-HC $(0.15 \mathrm{mM} \mathrm{CaCl})$ to the same medium containing $1.8 \mathrm{mM} \mathrm{CaCl}$ for $24 \mathrm{~h}$ induced a small increase in $1.3 \mathrm{kB}$ IL-6 transcript levels (Fig. 3A, left panel). In KGM-HC, IL-6 transcripts were not detectably induced $6 \mathrm{~h}$ after treatment with the following agents: $12-\mathrm{O}$-tetradecanoyl phorbol-13-acetate (TPA, Sigma St. Louis, MO, USA, $20 \mathrm{n} M$ ), recombinant human interleukin-1 $\alpha$ (rhIL-1 $\alpha$, Dainippon, Osaka, Japan, 5 or $100 \mathrm{U} / \mathrm{ml})$, ultraviolet-B irradiation $(100$ or $1000 \mathrm{~J} / \mathrm{m}^{2}$, Sylvnia FS-2 bulbs, through phosphate buffered saline, without lid), bovine bone transforming growth factor- $\beta$, Collagen Corp., Palo Alto, CA, USA), $10 \mathrm{ng} / \mathrm{ml}$ ), or E. coli lipopolysaccharide (LPS, Sigma, $100 \mu \mathrm{g} / \mathrm{ml}$ )
Table 1. Qualitative PCR analysis of IL-6 mRNA levels in normal and psoriatic epidermis

\begin{tabular}{lccc}
\hline & $\begin{array}{l}\text { Normal } \\
(n=25)\end{array}$ & $\begin{array}{l}\text { Psoriasis } \\
(n=20)\end{array}$ & $P$ value \\
\hline $\begin{array}{l}c \text {-abl-positive } \\
(\% \text { of total) }\end{array}$ & $21(84 \%)$ & $19(95 \%)$ & - \\
$\begin{array}{l}\text { EtBr-positive } \\
(\% \text { of } a b l \text {-positive) }\end{array}$ & $2(9.5 \%)$ & $6(32 \%)$ & 0.08 \\
$\begin{array}{l}\text { Blot-positive } \\
(\% \text { of } a b l \text {-positive) }\end{array}$ & $13(62 \%)$ & $15(79 \%)$ & 0.24 \\
$\begin{array}{l}\text { Strongly blot-positive } \\
(\% \text { of } a b l \text {-positive) }\end{array}$ & $2(9.5 \%)$ & $14(74 \%)$ & $<0.0001$ \\
\hline
\end{tabular}

a Visual estimate of intensity at least that of positive control (cycloheximide-treated keratinocyte RNA) 

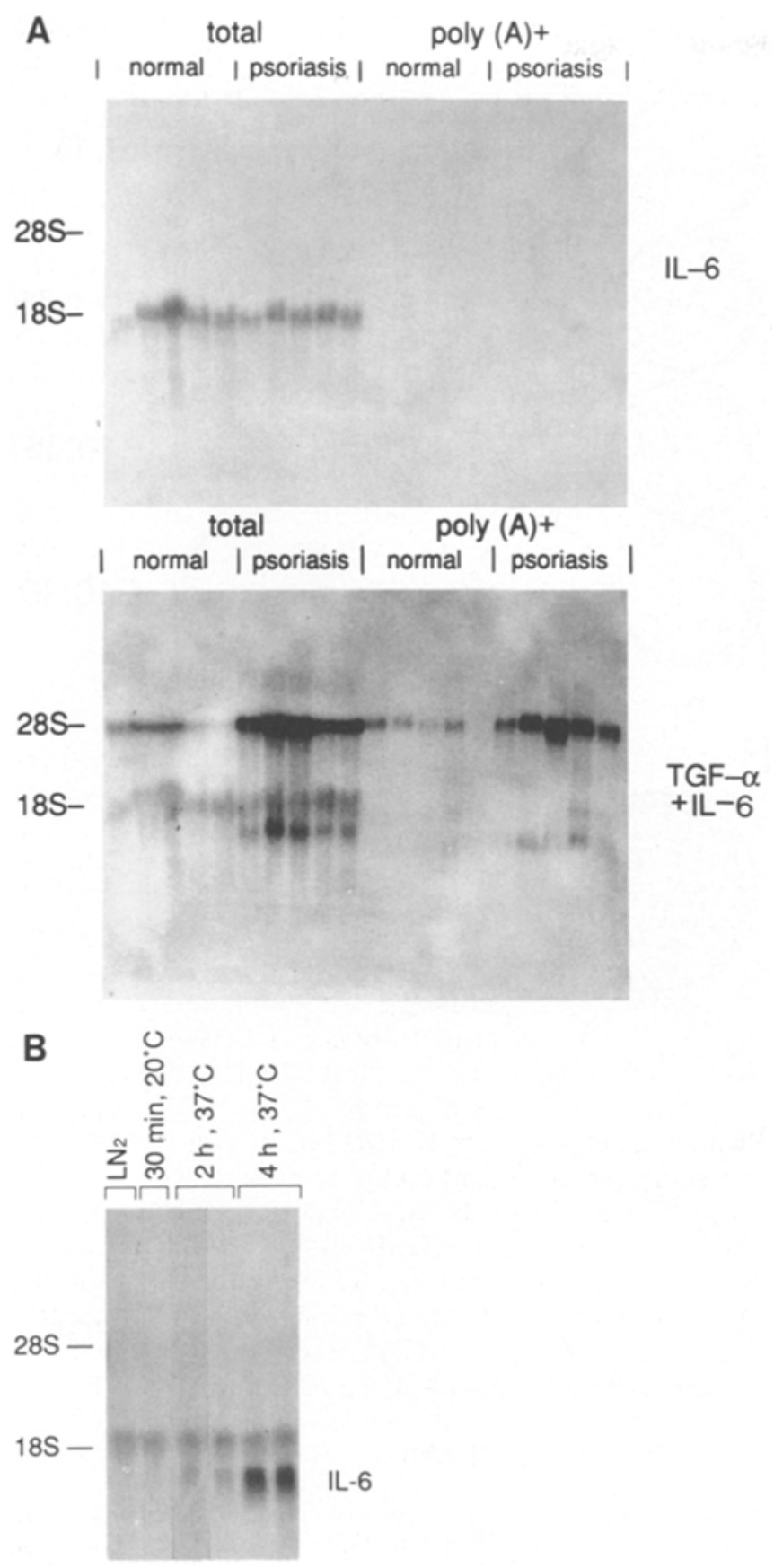

Fig. 1A, B. RNA blot analysis of IL-6 mRNA. A Comparison of IL- 6 and TGF- $\alpha$ mRNA levels in normal vs. psoriatic epidermis. Total RNA $(40 \mu \mathrm{g})$ or poly $(\mathrm{A})^{+}$RNA $(5 \mu \mathrm{g})$, isolated by a single cycle of oligo (dT) cellulose chromatography from the same individuals, were blotted and sequentially hybridized against an IL-6 probe (upper panel) or a mixture of IL-6 and TGF- $\alpha$ probes (lower panel). Mobilities of ribosomal RNAs are shown to the left. B Keratome strips were incubated in KBM under the conditions shown above the figure. RNA was extracted and $50 \mu \mathrm{g}$ total RNA from each condition was analyzed by blot hybridization. The expected mobility of IL-6 mRNA is indicated to the right, and the mobilities of ribosomal RNAs are shown to the left

(Fig. 3A, right panet). In experiments not shown, recombinant human tumor necrosis factor (rhTNF- $\alpha$, Amgen Thousand Oaks, CA, USA, $20 \mathrm{ng} / \mathrm{ml}$ ) either alone or in the presence of recombinant human interferon-gamma (rhIFN-gamma, Collaborative Research, Bedford, MA.,

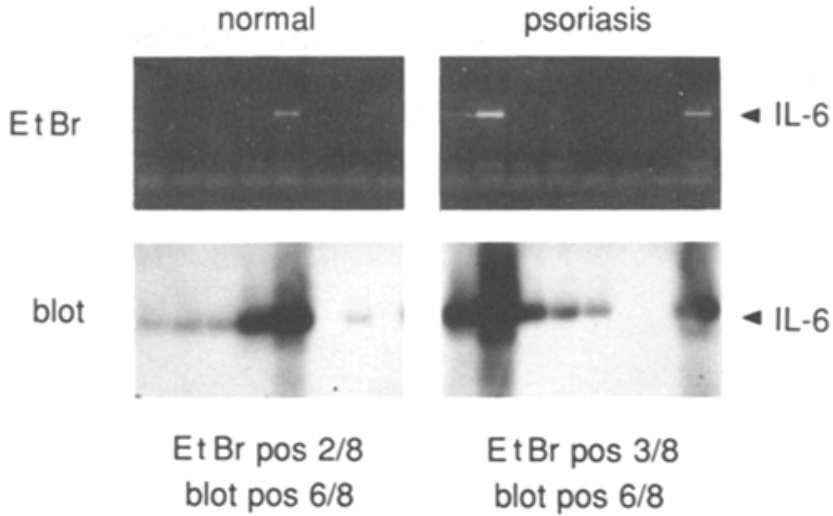

Fig. 2. Qualitative PCR analysis of IL-6 mRNA levels in normal and psoriatic epidermis. Upper panels display ethidium bromidestained gel, and lower panels display Southern blot of the same gel hybridized against the IL- 6 cDNA probe. The results of one of three experiments are shown

USA, $100 \mathrm{U} / \mathrm{ml}$ ) for 24 or $48 \mathrm{~h}$ also failed to induce detectable IL-6 mRNA. However, as shown in Fig. 3A, treatment with cycloheximide (CHX, $10-15 \mu \mathrm{g} / \mathrm{ml}, 2$ to $4 \mathrm{~h}$ ) consistently induced marked accumulation of IL-6 transcripts. No additional enhancement was observed when CHX was added $2 \mathrm{~h}$ prior to TPA, IL- $1 \alpha$, or UVB treatment (Fig. 3A). In marked contrast, IL-6 transcripts were detectable constitutively in adult human dermal fibroblasts, and could be strongly induced by treatment with the protein kinase $\mathrm{C}$ activators di-C8 and TPA (Fig. 3B). Similar results have been reported previously in the foreskin-derived fibroblast strain FS-4 [29].

\section{Mitogenic assays}

IL-6 demonstrated little or no effect on keratinocyte growth rate or maximum cell density when assayed under high-density conditions [48], either in the presence or absence of exogenous growth factors (data not shown). However, under these conditions, keratinocytes display marked cell proliferation in the absence of exogenous growth factors $[8,40,44,48]$. Therefore, we analyzed the proliferative effects of IL-6 at clonal density to minimize

Table 2. Semiquantitative PCR analysis of IL-6 mRNA levels in normal and psoriatic epidermis

\begin{tabular}{lccl}
\hline & $\begin{array}{l}\text { Normal } \\
(n=7)\end{array}$ & $\begin{array}{l}\text { Psoriasis } \\
(n=6)\end{array}$ & $P$ value \\
\hline $\begin{array}{l}\text { PCR score } \\
\text { mean }\end{array}$ & 0.46 & 5.69 & 0.05 \\
$\quad \pm$ SEM & \pm 0.08 & \pm 2.63 & \\
$\quad$ range & $0.23-0.87$ & $1.52-18.52$ & \\
log PCR score & & & \\
$\quad$ mean & -0.37 & 0.59 & 0.0001 \\
\pm SEM & \pm 0.07 & \pm 0.16 & \\
\hline
\end{tabular}

${ }^{a}$ Defined as IL-6 radioactivity (dpm) $/ \beta$-globin radioactivity (dpm) detected by phosphorimager after blot hybridization of PCR products against IL- 6 and $\beta$-globin probes 
A

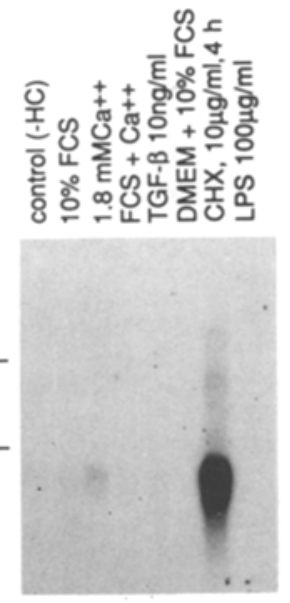

$5 \mu \mathrm{g}$ poly $\mathrm{A}^{+}$
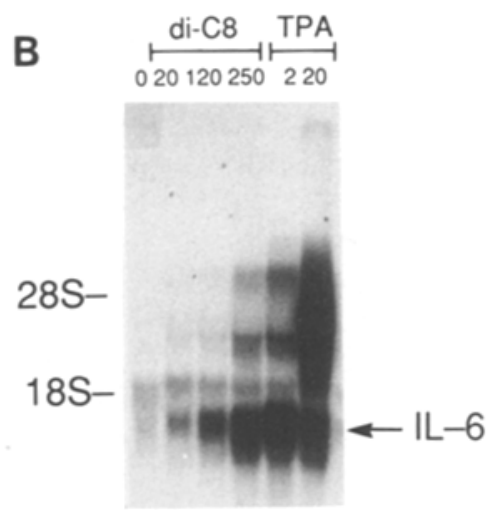

Fig. 3A, B. RNA blot analysis of IL-6 mRNA levels in cultured keratinocytes and fibroblasts. A Keratinocytes. Cells were grown in HC-deficient media for one passage prior to treatment. Left panel: neonatal keratinocytes were grown in MCDB 153 medium modified for high density growth [12]. With the exception of cycloheximide (CHX) treatment, which was for $4 \mathrm{~h}$, cells were treated as shown at the top of the Figure for $24 \mathrm{~h}$ prior to isolation of polyadenylated RNA (5 $\mu \mathrm{g} / \mathrm{lane})$. Right panel: adult keratinocytes were treated for $2 \mathrm{~h}$ with $\mathrm{CHX}$, then either with or without an additional $4 \mathrm{~h}$ of treatment with the agonists shown. Total RNA $(20 \mu \mathrm{g})$ was then analyzed by RNA blot hybridization. Expected mobility ofIL-6 mRNA is shown to thge right, and mobilities of ribosomal RNAs are shown to the left. B Fibroblasts. Confluent secondary cultures of human dermal fibroblasts were treated with the indicated concentrations of dioctanoylglycerol (di-C8, $\mu M$ ) or TPA $(\mathrm{n} M)$ for $4 \mathrm{~h}$ prior to RNA extraction. Expected mobility of IL-6 mRNA is shown to the right, and mobilities of ribosomal RNAs are shown to the left

potential autocrine effects of keratinocyte-derived growth factors. To test for EGF-like mitogenic effects, clonal growth assays were performed in the absence of EGF. Under these conditions, carrier-free, purified recombinant human IL-6 of known biological activity stimulated the clonal growth of keratinocytes at $10 \mathrm{ng} / \mathrm{ml}$, albeit to a lesser extent than did EGF (Fig. 4A). However, in the absence of insulin, IL-6 had no growth-promoting effect (Fig. 4A). The growth-promoting effects of IL-6 were completely inhibited by anti-EGF receptor monoclonal antibodies, but not by isotype-matched antibodies against human growth hormone (Fig. 4B). In contrast, anti-EGF

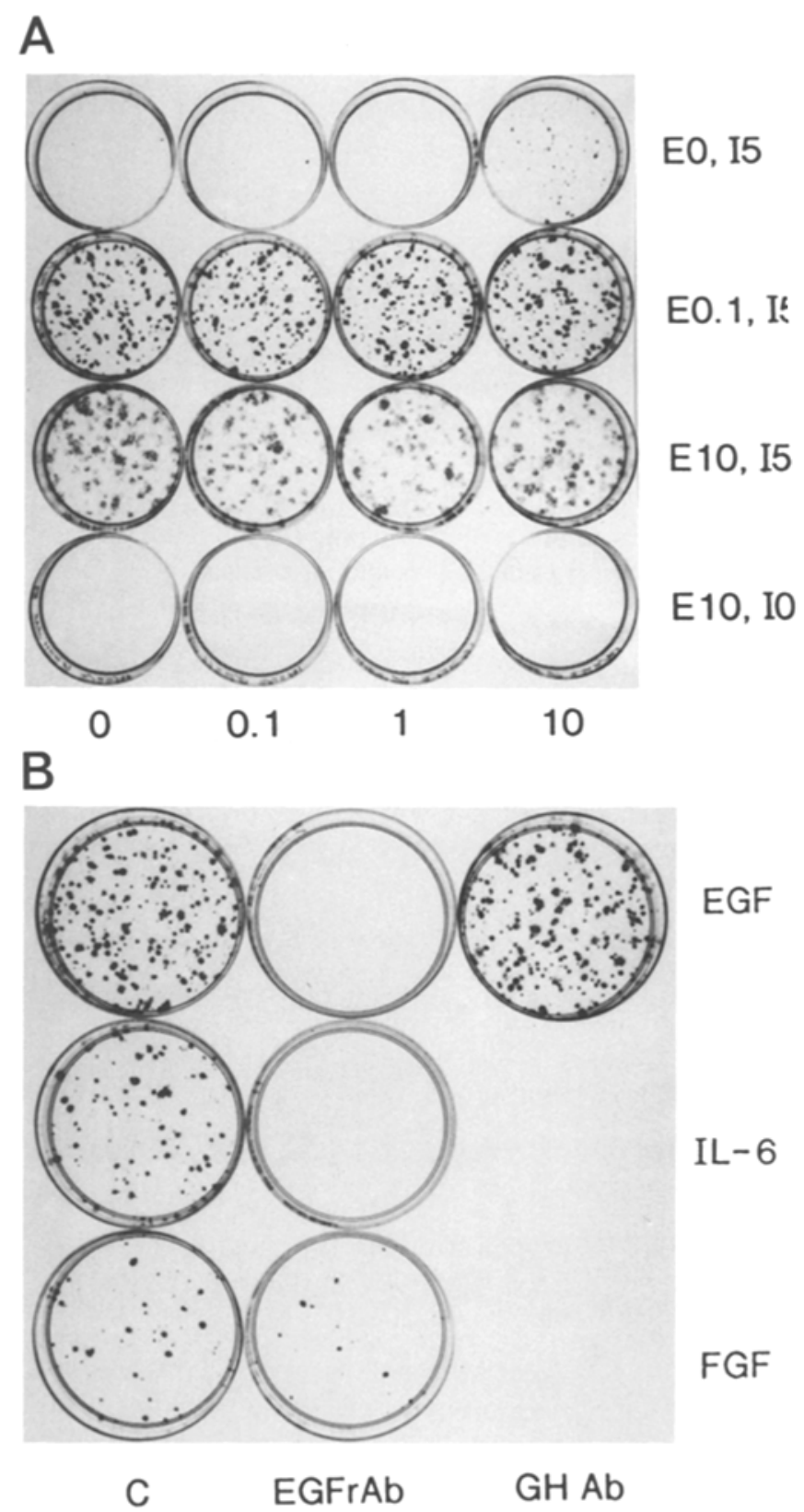

Fig. 4A, B. EGF-like effects of rhIL-6 on clonal keratinocyte growth. A IL-6 substitutes for EGF, but not for insulin. MCDB 153 (without BPE) was supplemented with EGF ( $E$, in $\mathrm{ng} / \mathrm{ml})$ and insulin $(I$, in $\mu \mathrm{g} / \mathrm{ml})$ at the concentrations indicated to the right of the Figure, and IL-6 (in ng/ml) as indicated below the figure. B Inhibition of rhIL-6-stimulated keratinocyte growth by anti-EGF receptor monoclonal antibodies. Keratnocytes were plated in MCDB 153 without BPE in the presence of insulin $(5 \mu \mathrm{g} / \mathrm{ml})$ and the factors indicated to the left of the Figure: EGF (10 ng/ml), IL-6 (10 ng/ml), or bFGF $(10 \mathrm{ng} / \mathrm{ml})$. At the time of plating, $\mathrm{mAbs}$ were also added as indicated at the bottom of the Figure: none $(C)$, anti-EGF receptor $\mathrm{mAb}$ (EGFRAb), or growth hormone $\mathrm{mAB}(G H a b)$.

receptor antibodies had little or no effect on the stimulation of clonal keratinocyte growth by basic fibroblast growth factor (Fig. 4B).

In the course of these studies, we observed that certain preparations of IL- 6 containing high amounts of total protein were able to substitute for insulin in stimulating 


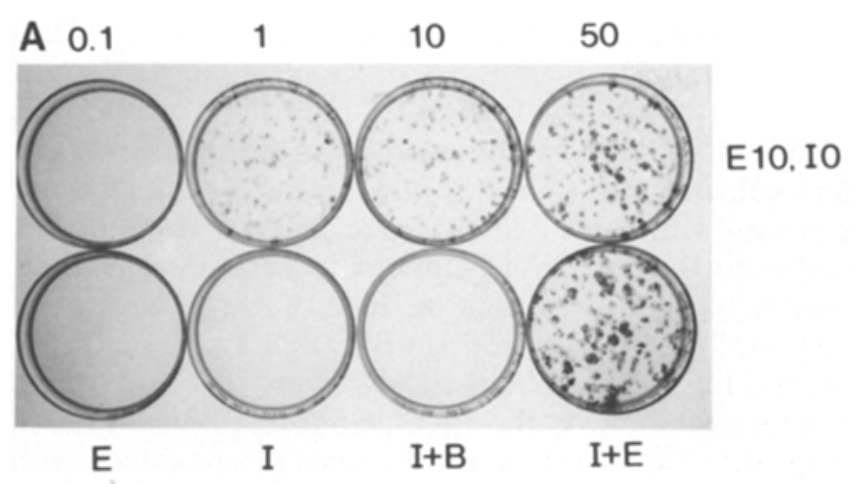

B

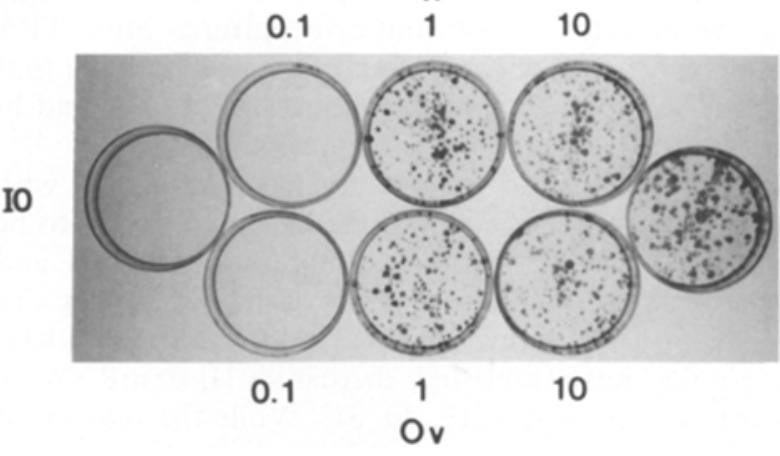

Fig. 5A, B. Insulin-like effects of various proteins on clnal keratinocyte growth. Cultures were fixed, stained, and photographed after 10 days of incubation. A Effects of BSA. Top row: cells were plated in MCDB 153 supplemented with $\operatorname{EGF}(E, 10 \mathrm{ng} / \mathrm{ml})$ in the presence of the concentrations of BSA (in $\mu \mathrm{g} / \mathrm{ml}$ ) shown above the Figure. Bottom row: cells were plated in MCDB 153 supplemented with: EGF $(E, 10 \mathrm{ng} / \mathrm{ml}) ;$ insulin $(I, 5 \mu \mathrm{g} / \mathrm{ml})$; insulin $(I, 5 \mu \mathrm{g} / \mathrm{ml})$ and BSA $(B, 50 \mu \mathrm{g} / \mathrm{ml})$; or insulin and EGF $(I+E)$. B Effects of transferrin $\left(T_{r}\right)$ and ovalbumin $(O v)$. Cultures were plated in MCDB containing EGF $(10 \mathrm{ng} / \mathrm{ml}$ ) in the absence of insulin (except for the rightmost dish, (I5) which received $5 \mu \mathrm{g} / \mathrm{ml}$ insulin), in the presence of $\operatorname{Tr}$ or $\mathrm{Ov}$ at the concentrations (in $\mu \mathrm{g} / \mathrm{ml}$ ) indicated above and below the figure

clonal keratinocyte growth (data not shown). Therefore, we tested the effects of bovine serum albumin (BSA) as well as transferrin and ovalbumin on clonal keratinocyte growth in the absence of added insulin. Each of these proteins markedly stimulated keratinocyte growth at concentrations as low a $1 \mu \mathrm{g} / \mathrm{ml}$, provided that EGF was present (Fig. 5A and B). In addition, Fig. 5A demonstrates that BSA substitutes for insulin, but not for EGF, as a growth-promoting additive.

\section{Discussion}

Studies involving transplantation of psoriatic skin to murine recipients suggest that the initiating and/or propagating mechanisms for psoriatic epidermal hyperplasia do not reside exclusively within the epidermis, but rather within an abnormal cutaneous microenvironment containing dermal cells, immune/inflammatory cells, and circulating factors $[5,16,24]$. Nevertheless, overexpression of a keratinocyte mitogen in an autocrine fashon might be an important final common pathway mediating psoriatic epidermal hyperplasia. In these studies, we re-examined previous findings of IL-6 expression in psoriasis $[9,30-34]$ in order to investigate further the hypothesis that overexpression of IL- 6 by keratinocytes might be important in the pathogenesis of psoriatic epidermal hyperplasia.

We initially used RNA blot hybridization for this purpose, because the results confirm that a transcript of the expected sze is being detected. Although limited sensitivity is the principal disadvantage of this technique, this problem is often overestimated. RNA blot hybridization is capable of detecting approximately $10^{5}$ to $10^{6}$ target molecules [21]. Given an estimate of approximately $10 \mathrm{pg}$ of RNA per cell [42], $40 \mu \mathrm{g}$ total RNA represents approximately $4 \times 10^{6}$ cells. Therefore, blots loaded with $40 \mu \mathrm{g}$ total RNA should detect from less than one to a few transcripts per cell. Keratome biopsies contain approximately the same amount of RNA and DNA (unpublished data). The double-stranded probe will detect genomic sequences from both strands of each parental chromosome, and therefore $10 \mu \mathrm{g}$ genomic DNA and $40 \mu \mathrm{g}$ total RNA should yield approximately the same hybridization if the target RNA sequence is present at a level of one copy per cell. Consistent with these estimates, we routinely obtain strong positive hybridization to DNA blots containing $10 \mu \mathrm{g}$ genomic DNA $[11,12]$.

Under these conditions, IL-6 transcripts were not detectable by RNA blot analysis in normal or psoriatic epidermal keratome biopsies (Fig. 1A, upper panel). Moreover, non-specific hybridization to $18 \mathrm{~S}$ ribosomal RNA was demonstrated, and could be eliminated by selection of polyadenylated RNA. In contrast, 5.0 and $1 .-6 \mathrm{~kb}$ TGF- $\alpha$ transcripts were clearly detectable under all conditions, and were markedly and uniformly elevated in psoriatic lesions relative to normal skin [10] (Fig. 1A, lower panel). Although its physiologic significance is unclear, the demonstration of IL-6 transcripts after organ culture of normal keratome biopsies (Fig. 1B) shows that it is possible to detect IL-6 transcripts under our conditions of RNA isolation from skin tissue. The nuclear protooncogenes $c$-fos, $c$-jun, and c.myc undergo similar, but much more marked, induction in organ culture [11], and similarities in the regulation of IL-6 and $c$-fos gene expression have been noted [39]. From these results, we conclude that IL-6 transcripts are expressed at a very low level in both normal and psoriatic keratome biopsies, at levels of less than one to at most a few copies per cell when averaged over the tissue sampled.

In order to explore IL-6 expression in keratome biopsies levels less than one copy per cell, we analyzed RNA samples by reverse transcription and PCR. Making use of conditions designed to optimize sensitivity, titration of linearized IL-6 plasmid DNA demonstrated that it was possible to detect 1.5 molecules of linearized IL-6 plasmid DNA per reaction (data not shown). Assuming only a $1 \%$ efficiency of cDNA synthesis, this assay would still detect approximately one IL-6 molecule per 1000 cells $\left(1 \mu \mathrm{g} /\right.$ reaction $\times 10^{5}$ cells $/ \mu \mathrm{g}$ RNA $\times 0.01$ efficiency factor $=10^{3}$ cells). Although this analysis revealed no difference in the number of individuals in whom IL-6 was detectable, the number of psoriatics displaying a strongly positive signal after blot hybridization of the PCR was 
clearly increased (Table 1). Therefore, semiquantitative PCR analysis was undertaken, using experimental conditions designed to maintain a linear response to input RNA. This analysis revealed uniformly low expression of IL-6 in normal biopsies, and highly variable but significantly elevated expression in psoriatic biopsies (Table 2).

The cellular source of the IL-6 transcripts detected in keratome biopsies by PCR is not clear, since tissue sampled by this method contains small numbers of dermal fibroblasts, endothelial cells, smooth muscle cells, and variable numbers of macrophages, all known to be robust sources of IL-6 [1, 27]. Even if techniques for dermal-epidermal separation were employed, other potential sources of IL-6, such as Langerhans cells, melanocytes and epidermal macrophages, could not be excluded. Moreover, the results shown in Fig. 1B indicate that the tissue manipulations required for such separations could lead to artifactual expression of IL-6 mRNA. Despite these limitations, several lines of evidence favor the concept that much, if not all, of the increased IL-6 expression in psoriatic lesions is derived from fibroblasts and/or infiltrating inflammatory cells rather than from keratinocytes.

Analysis of the in vivo blot hybridization data (Fig. 1) indicates that IL-6 transcripts are only present at less than one to a few copies per cell on average over the tissue. Since at least some of this signal is likely to be derived from infiltrating macrophages and contaminating dermal tissue, the amount derived from keratinocytes is likely to be even lower than this. Moreover, variability of lesional IL-6 mRNA levels was detected by semiquantitative PCR (Table 2). This would be most consistent with the presence of variable numberrs of infiltrating mononuclear cells and/or variable dermal contamination. Certainly, if IL-6 expression is occurring in lesional keratinocytes, it must be quite heterogeneous within a lesion or from lesion to lesion. In this regard, Ohta et al. gave suggested that IL-6 expression is found at the advancing borders of psoriatic plaques [31].

Several studies have reported increased IL-6 immunoreactivity within the epidermal compartment [19, 30-34]. However, despite the demonstration that immunostaining can be blocked by preincubation with purified antigen, it can be difficult to prove that the observed staining actually reflects the presence of tissue antigen in the absence of corroborating biochemical evidence. Under conditions in which $10 \mathrm{ng}$ of purified recombinant IL-6 was readily detectable, we were unable to detect any band which comigrated with it by immunoblot analysis of nonionic detergent lysates of normal or psoriatic keratome biopsies (data not shown). Moreover, this analysis failed to reveal any band which was increased in psoriatic lesions relative to normal skin (data not shown). Even if IL-6 protein is present in the epidermis at levels too low to be detected by immunoblotting, it is possible that it may be derived from the circulation, and not from keratinocytes [38]. In this regard, the skin is apparently a major site of binding and catabolism of systemically-administered IL-6 [7] and TNF- $\alpha$ [2].

Blot hybridization analysis of keratinocytes propaga- ted in the absence of $\mathrm{HC}$ revealed very low levels of IL-6 mRNA (Fig. 3A). In contrast, other keratinocyte-derived transcripts, including TGF $-\alpha$ [10] and CRABP-II [13], are readily detectable by this method in normal epidermis and cultured keratinocytes [12], and are markedly and constantly increased in psoriatic lesions. IL-6 mRNA could not be detectably induced in keratinocytes by a variety of agonists, including IL $1 \alpha$, TPA, IFN-gamma, TNF- $\alpha$, TGF- $\beta$, LPS, and UVB irradiation. In contrast, dermal fibroblasts expressed abundant IL-6 transcripts after stimulation by the PKC agonists TPA and di-C8 (Fig. 3B). These results are, in general, consistent with other studies of IL-6 expression in cultured KC [22, 26, 35]. However, Kirnbauer et al. [22] found that IL-6 mRNA could be detected in keratinocyte cultures after TPA treatment. Among other explanations, it is possible that the small number of fibroblasts that are often found in these cultures could explain this discrepancy.

Taken together, our results are most consistent with those of Gillitzer et al., who found IL-6 expression to be localized to the vicinity of dermal blood vessels and absent from the epidermis in psoriatic skin by in situ hybridization [18]. However, three other in situ hybridization studies have reported increased IL-6 mRNA in psoriatic keratinocytes $[19,30,31]$. While the reason for these discrepancies is not clear, our observaton of nonspecific hybridization of IL-6 to 18S rRNA (Fig. 1A) indicates that in situ hybridization results should be interpreted with caution. Our results are also consistent with those of Gearing et al. [17], who were unable to detect IL-6 biological activity in psoriatic scale despite its reported presence $\mathrm{n}$ psoriatic suction blister fluid (37). Nevertheless, it remains possible that psoriatic keratinocytes express elevated, albeit very low, amounts of IL-6 mRNA.

Although unresponsive to cytokine treatment or PKC activators, IL-6 mRNA was strongly induced by cycloheximide (CHX) in cultured keratinocytes (Fig. 3). it is possible that an unstable protein (which would be rapidly depleted after CHX treatment) normally functions to destabilize IL-6 transcripts in keratinocytes, as has been observed for GM-CSF mRNA in other cell types [43]. Like other cytokine genes which appear to be regulated at the level of RNA stability [6], IL-6 contains an AT-rich domain in its $3^{\prime}$ untranslated region [49]. Recently, IL- 6 mRNA stability has been shown to be increased in response to TNF- $\alpha$ in IL-1.stimulated fibroblasts [14]. Whether this mechanism contributes to the induction of IL-6 mRNA observed in keratome biopsy organ cultures (Fig. 1B) remains to be determined.

Whether produced by keratinocytes in an autocrine mode, by dermal and/or inflammatory cells in a paracrine mode, or by other cells in an endocrine mode, IL- 6 could play an important role in the regulation of epidermal growth. To this end, we confirm previous reports $[19,25$, $40]$ of the mitogenicity of IL-6 for human keratinocytes, albeit with reduced potency relative to EGF/TGF- $\alpha$ or bFGF. Demonstration of IL- 6 mitogenicity required the use of clonal, rather than high-density conditions, and was observed only in the presence of insulin and the absence of EGF. Surprisingly, stimulation of keratinocyte 
growth by IL-6 could be blocked by monoclonal antibodies directed against the EGF receptor (Fig. 4B), suggesting that the EGF receptor signal transduction system may be a dosnstream mediator of IL-6 action in keratinocytes. In addition, BSA, transferrin, and ovalbumin could all substitute for insulin in promoting keratinocyte growth at concentrations as low as $1 \mu \mathrm{g} / \mathrm{ml}$, suggesting that the growth-promoting effects of insulin may not be mediated via specific insulin/IGF-1 receptors in keratinocytes. These results demonstrate that the mitogenic effects of cytokine preparations containing large amounts $(\geq 1 \mu \mathrm{g} / \mathrm{ml})$ of carrier proteins should be interpreted with caution when assayed under serum-free conditions.

Clearly, these results do not exclude the possibility that IL-6 is expressed by psoriatic keratinocytes in vivo. However, they do strongly suggest that lesional keratinocytes do not express high levels of this cytokine, despite being markedly hyperproliferative. Whatever its source, IL-6 is undoubtedly present in the psoriatic millieu, and we confirm that this cytokine can be mitogenic for keratinocytes under appropriate experimental conditions. However, on the basis of the results of the anti-EGF receptor blocking experiments presented here, it appears that IL-6 may act indirectly to modulate the effects of TGF- $\alpha$ and/or other EGF receptor ligands on epidermal proliferation. For all these reasons, we do not favor the notion that IL-6 is a major autocrine mitogen for psoriatic keratinocytes. It is to be hoped that future studies of the immunogenetic basis of psoriasis will eventually elucidate the roles of IL-6, as well as other cytokines and growth factors, in the pathogenesis of this complex disease.

Acknowledgements. The skilled technical assistance of Qiong Yang, Li Qin, Tim Jensen, and Matt Cromie is greatly appreciated. We are grateful to Drs. P. B. Sehgal and L. T. May of Rockefeller University for the IL-6 cDNA probe, to Dr. Judith Abraham of California Biotechnology for bFGF, and to Dr. Rik Derynck of Genentech for the TGF- $x$ probe and anti-GH antibody.

This study was supported in part by U.S.P.H.S. Grants R29AR40016 (JTE) and R29-AR39691 (GJF), the Babcock Memorial Trust (JTE, GJF) and the J. W. Kieckhefer and Mayo foundations (MRP).

\section{References}

1. Aarden LA, De Groot ER, Schaap OL, Lansdorp PM (1987) Production of hybridoma growth factor by human monocytes. Eur J Immunol 17: 1411-1416

2. Beutler BA, Milsark IW, Cerami A (1985) Cachectin/tumor necrosis factor: production, distribution, and metabolic fate in vivo. J Immunol 135: 3972-3977

3. Birnboim HC, Doly $J$ (1979) A rapid alkaline extraction procedure for screening recombinant plasmid DNA. Nucleic Acids Res 7: 1513

4. Bos JD, Hulsebosch HJ, Krieg SR, Bakker PM, Cormane RH (1983) Immunocompetent cells in psoriasis: in situ immunophenotyping by monoclonal antibodies. Arch Dermatol Res 275: $181-189$

5. Briggaman RA (1982) Epidermal-dermal interactions in adult skin. J Invest Dermatol 79: 21S-24S

6. Caput D, Beutler B, Hartog K, Thayer R, Brown-Shimer S, Cerami A (1986) Identification of a common nucleotide se- quence in the 3 -untranslated region of mRNA molecules specifying inflammatory mediators. Proc Natl Acad Sci USA 83: $1670-1674$

7. Castell J, Klapproth J, Gross V, Walter E, Andus T, Snyers L, Content J, Heinrich RC (1990) Fate of interleukin-6 in the rat: involvement of skin of its catabolism. Eur J Biochem 189: $113-118$

8. Cook PW, Pittelkow MR, Shipley GD (1991) Growth factorindependent proliferation of normal human neonatal keratinocytes: production of autocrine- and paracrine-acting mitogenic factors. J Cell Physiol 146: 277-289

9. Derynck R, Roberts AOB, Winkler M, Chen EQ, Goeddel DV (1984) Human transforming growth factor- $\alpha$ : precursor structure and expression in E. coli. Cell 38: 287-297

10. Elder JT, Fisher GJ, Lindquist PB, Bennett GL, Pittelkow MR, Coffey RJ Jr., Ellingsworth L, Derynck R, Voorhees JJ (1989) Overexpression of transforming growth factor $\alpha$ in psoriatic epidermis. Science 243: 811-814

11. Elder JT, Tavakkol A, Klein SB, Zeigler ME, wicha M, Voorhees JJ (1990) Protooncogene expression in normal and psoriatic skin. J Invest Dermatol 94: 19-25

12. Elder JT, Fisher GJ, Zhang Q-Y, Eisen D, Krust A, Kastner P, Chambon P, Voorhees JJ (1991) Retinoic acid receptor gene expression in human skin. J Invest Dermatol 96: 425-433

13. Elder JT, Strom A, Pettersson U, Tavakkol A, Griffiths CEM, Krust A, Kastner P, Chambon P, Voorhees JJ (1992) Differential regulation of retinoid acid receptors and binding proteins in human skin. J Invest Dermatol 98: 673-679

14. Elias JA, Lentz V (1990) IL-1 and tumor necrosis factor synergistically stimulate fibroblast IL-6 production and stabilize IL-6 messenger RNA. J Immunol 145: 161-166

15. Feinberg AP, Vogelstein B (1983) A technique for radiolabeling DNA restriction endonuclease fragments to high specific activity. Anal Biochem 132: 6-13

16. Fraki JE, Briggaman RA, Lazarus GS (1982) Uninvolved skin from psoriatic patients develops signs of involved psoriatic skin after being grafted onto nude mice. Science 215: 685-687

17. Gearing AJH, Fincham NJ, Bird CR, Wadhwa M, Meager A, Cartwright JE, Camp RDR (1990) Cytokines in skin lesions of psoriasis. Cytokine 2: $68-75$

18. Gillitzer R, Berger R, Mielke V, Muller C, Wolff K, Stingl G (1991) Upper keratinocytes of psoriatic skin lesions express high levels of NAP-1/IL-8 mRNA in situ. $J$ Invest Dermatol 97: $73-79$

19. Grossman RM, Krueger J, Yourish D, Granelli-Piperno A, Murphy DP, May LT, Kupper TS, Sehgal PB, Gottlieb AB (1989) Interleukin 6 is expressed in high levels in psoriatic skin and stimulates proliferation of cultured human keratinocytes. Proc Natl Acad Sci USA 86: 6367-6371

20. Hirano T, Akira S, Taga T, Kishimoto T (1990) Biological and clinical aspects of interleukin 6. Immunol Today 11: 443-449

21. Kawasaki ES (1990) Amplification of RNA. In: Innis MA, Gelfand DH, Sninsky JJ (eds) PCR protocols: a guide to methods and applications. Academic Press, New York, pp 21-27

22. Kirnbauer R, Kock A, Schwarz T, Urbanski A, Krutmann J, Borth W, Damm D, Shiplye G, ansel JC, Luger TA (1989) IFN- $\beta 2, \mathrm{~B}$ cell differentiation factor 2 , or hybridoma growth factor (IL-6) is expressed and released by human epiderma cells and epidermoid carcinoma cell lines. J Immunol 142: 1922-1928

23. Kishimoto $\mathrm{T}$ (1989) The biology of interleukin-6. Blood 74: 10

24. Kreuger GG, Chambers DA, Shelby J (1981) Involved and uninvolved skin from psoriatic subjects: are they equally diseased? Assessment by skin transplanted to congenitally athymic (nude) mice. J Clin Invest 68: 1548-1557

25. Krueger J, Ray A, Tamm I, Sehgal PB (1991) Expression and function of interleukin- 6 in epithelial cells. J Cell Biochem 45: $327-334$

26. Kupper T, Min K, Sehgal P, Mizutani H, Birchall N, Ray A (1989) Production of IL-6 by keratinocytes: implications for epidermal inflammation and immunity. Ann NY Acad Sci 557: $454-465$ 
27. Loppnow H, Libby P (1990) Proliferating or interleukin 1activated human vascular smooth muscle cells secrete copious interleukin 6. J Clin Invest 85: 731-738

28. May LT, Helfgott DC, Sehgal PB (1986) Anti- $\beta$-interferon antibodies inhibit the increased expression of HLA-B7 mRNA in tumor necrosis factor-treated human fibroblasts: structural studies of the $\beta 2$-interferon involved. Proc Natl Acad Sci USA 83: 8957-8961

29. May LT, Ghrayeb J, Santhanam U, Tatter SB, Sthoeger Z, Helgott DC, Chiorazzi N, Grieninger G, Sehgal PB (1988) synthesis and secretion of multiple forms of $\beta 2$-interferon/B-cell differentiation factor $2 /$ hepatocyte-stimulating factor by human fibroblasts and monocytes. J Biol Chem 263: 7760-7766

30. Neuner P, Urbanski A, Trautinger F, Moller A, Kirnbauer R, Kapp A, Schopf E, Schwarz T, Luger TA (1991) Increased IL-6 production by monocytes and keratinocytes in patients with psoriasis. J Invest Dermatol 97: 27-33

31. Ohta Y, Katayama I, Funato T, Yokozeki H, Nishiyama S, Hirano T, Kishimoto T, Nishioka K (1991) In situ expression of messenger RNA of interleukin- 1 and interleukin- 6 in psoriasis: interleukin- 6 involved in formation of psoriatic lesions. Arch Dermatol Res 283: 351-356

32. Oxholm A, Oxholm P, Staberg B, Bendtzen K (1989) Expression of interleukin-6-like molecules and tumour necrosis factor after topical treatment of psoriasis with a new vitamin D analogue (MC903). Acta Derm Venereol (Stockh) 69:385-390

33. Oxholm A, Oxholm P, Staberg B, Bendtzen K (1989) Interleukin- 6 in the epidermis of patients with psoriasis before and during PUVA treatment. Acta Derm Venereol (Stockh) 69: 195-199

34. Oxhom A, Diamant M, Oxhom P, Bendtzen K (1991) Interleukin-6 and tumor necrosis factor alpha are expressed by keratinocytes but not by Langerhans cells. APMIS 99: 58-64

35. Partridge M, Chantry D, Turner M, Feldmann M (1991) Production of interleukin- 1 and interleukin- 6 by human keratinocytes and squamous cell lines. J Invest Dermatol 96: 771-776

36. Pittelkow MR, Scott RE (1986) New techniques for the in vitro culture of human skin keratinocytes and perspectives on their use for grafting of patients with extensive burns. Mayo Clin Proc 61: 771-777

37. Prens EP, Benne K, van Damma J, Bakkus M, Brakel K, Benner $R$, van Joost $T$ (1990) Interleukin-1 and interleukin-6 in psoriasis. J Invest Dermatol 95: 121S-124S

38. Rabilloud T, Asselineau D, Darmon M (1989) Presence of serum albumin in normal human epidermis: Possible implications for the nutrition and physiology of stratified epithelia. Mol Biol Rep 13: 213-219
39. Ray A, Sassone-Corsi P, Sehgal PB (1989) A multiple cytokineand second messenger-responsive element in the enhancer of the human interleukin-6 gene: similarities with c-fos gene regulation. Mol Cell Biol 9: 5537-5547

40. Ristow HJ (1990) Interleukin-1 does not stimulate DNA synthesis of cultured human keratinocytes growth-arrested in growth-factor-depleted medium. J Invest Dermato1 95: 688-692

41. Roth MS, Antin JH, Bingham EL, Ginsburg D (1989) Detection of Philadelphia chromosome-positive cells by the polymerase chain reaction following bone marrow transplant for chronic myelogeneous leukemia. Blood 74: 882-885

42. Sambrook J, Fritsch EF, Maniatis T (1989) Extraction, purification, and analysis of messenger RNA from eukaryotic cells. In: Sambrook J, Fritsch EF, Maniatis T (eds) Molecular cloning: a laboratory manual. Cold Spring Harbor Laboratory Press, Cold Spring Harbor, NY, Section 7.2

43. Shaw $G$, Kamen R (1986) A conserved AU sequence from the $3^{\prime}$ untranslated region of GM-CSF mRNA mediates selective mRNA degradation. Cell 46: 659-667

44. Shipley GD, Keeble WW, Hendrickson JE, Coffey RJ, Pittelkow MR (1989) Growth of normal human keratinocytes and fibroblasts in serum-free medium is stimulated by acidic and basic fibroblast growth factor. J Cell Physiol 138: 511-518

45. Urbanski A, Schwarz T, Neuner P, Krutmann J, Kirnbauer R, Kock A, Luger TA (1990) Ultraviolet light induces increrased circulating interleukin-6 in humans. J Invest Dermatol 94: $808-811$

46. Voorhees JJ, Duell EA, Bass LJ, Powell JA, Harrell ER (1972) Decreased cyclic AMP in the epidermis of lesions of psoriasis. Arch Dermatol 105: 701

47. Weinstein GD, McCullough JL, Ross PA (1985) Cell kinetic basis for pathophysiology of psoriasis. J Invest Dermatol 85 : 579-583

48. Wille JJ Jr, Pittelkow MR, Shipley GD, Scott RE (1984) Integrated control of growth and differentiation of normal human prokeratinocytes cultured in serum-free medium: clonal analyses, growth kinetics, and cell cycle studies. J Cell Physiol 121: $31-44$

49. Yasukawa K, Hirano T, Watanabe $Y$, Muratani K, Matsuda T, Nakai S, Kishimoto T (1987) Structure and expression of human B cell stimulatory factor-2 (BSF-2/IL-6) gene. Embo J 6: $2938-2945$

50. Yoshizaki K, Nishimoto N, Matsumoto K, Tagoh H, Taga T, Deguchi Y, Kuritani T, Hirano T, Hashimoto K, Okada N, Kishimoto T (1990) Interleukin 6 and expression of its receptor on epidermal keratinocytes. Cytokine 2: 381-387 